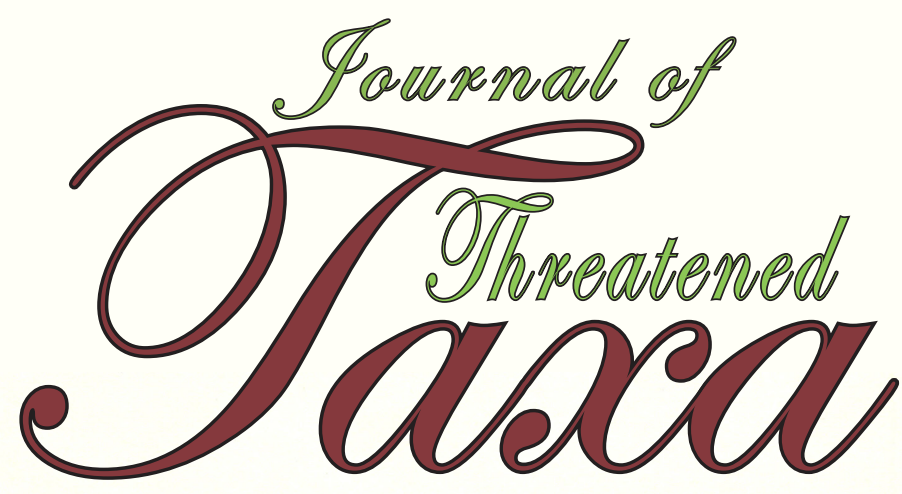

10.11609/jott.2021.13.14.20143-20310 enever.threatenedtaxa.org

26 December 2021 (Online \& Print) Val. 13 | Na. 14 | Pages: 20143-20310 155n 0974-7907 (Online) 155n 0974-7893 (Print)

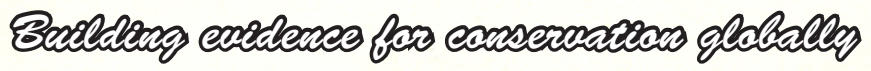

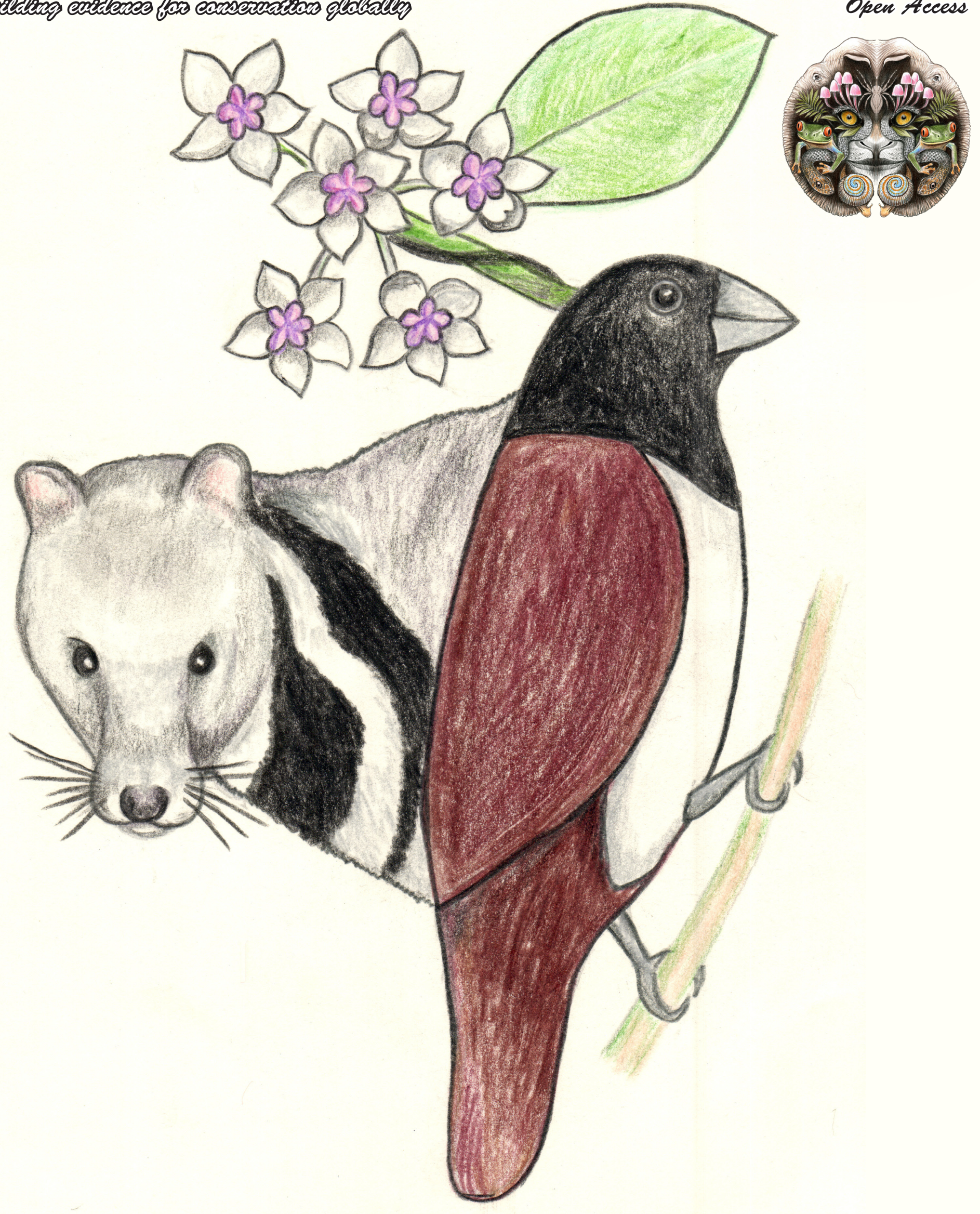

Open Access 


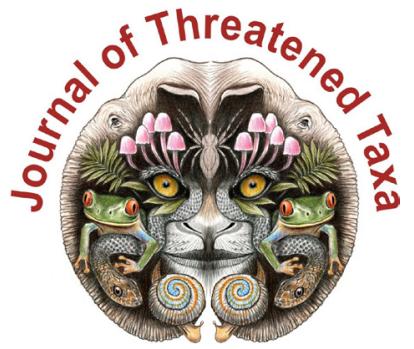

ISSN 0974-7907 (Online); ISSN $0974-7893$ (Print)

Publisher

Host

Wildlife Information Liaison Development Society

www.wild.zooreach.org

Zoo Outreach Organization www.zooreach.org

No. 12, Thiruvannamalai Nagar, Saravanampatti - Kalapatti Road, Saravanampatti, Coimbatore, Tamil Nadu 641035, India

Ph: +91 9385339863 | www.threatenedtaxa.org

Email: sanjay@threatenedtaxa.org

EDITORS

\section{Founder \& Chief Editor}

Dr. Sanjay Molur

Wildlife Information Liaison Development (WILD) Society \& Zoo Outreach Organization (ZOO),

12 Thiruvannamalai Nagar, Saravanampatti, Coimbatore, Tamil Nadu 641035, India

\section{Deputy Chief Editor}

Dr. Neelesh Dahanukar

Noida, Uttar Pradesh, India

\section{Managing Editor}

Mr. B. Ravichandran, WILD/ZOO, Coimbatore, India

\section{Associate Editors}

Dr. Mandar Paingankar, Government Science College Gadchiroli, Maharashtra 442605, India

Dr. Ulrike Streicher, Wildlife Veterinarian, Eugene, Oregon, USA

Ms. Priyanka lyer, ZOO/WILD, Coimbatore, Tamil Nadu 641035, India

Dr. BA. Daniel, $200 / \mathrm{WILD}$, Coimbatore, Tamil Nadu 641035, India

\section{Editorial Board}

Dr. Russel Mittermeie

Executive Vice Chair, Conservation International, Arlington, Virginia 22202, USA

\section{Prof. Mewa Singh Ph.D., FASc, FNA, FNASc, FNAPsy}

Ramanna Fellow and Life-Long Distinguished Professor, Biopsychology Laboratory, and Institute of Excellence, University of Mysore, Mysuru, Karnataka 570006, India; Honorary Professor, Jawaharlal Nehru Centre for Advanced Scientific Research, Bangalore; and Adjunct Professor, National Institute of Advanced Studies, Bangalore

\section{Stephen D. Nash}

Scientific Illustrator, Conservation International, Dept. of Anatomical Sciences, Health Sciences Center, T-8, Room 045, Stony Brook University, Stony Brook, NY 11794-8081, USA

\section{Dr. Fred Pluthero}

Toronto, Canada

\section{Dr. Priya Davidar}

Sigur Nature Trust, Chadapatti, Mavinhalla PO, Nilgiris, Tamil Nadu 643223, India

\section{Dr. Martin Fisher}

Senior Associate Professor, Battcock Centre for Experimental Astrophysics, Cavendish

Laboratory, JJ Thomson Avenue, Cambridge CB3 OHE, UK

\section{Dr. John Fellowes}

Honorary Assistant Professor, The Kadoorie Institute, 8/F, T.T. Tsui Building, The University of Hong Kong, Pokfulam Road, Hong Kong

\section{Prof. Dr. Mirco Solé}

Universidade Estadual de Santa Cruz, Departamento de Ciências Biológicas, Vice-coordenado do Programa de Pós-Graduação em Zoologia, Rodovia Ilhéus/Itabuna, Km 16 (45662-000)

Salobrinho, Ilhéus - Bahia - Brasil

\section{Dr. Rajeev Raghavan}

Professor of Taxonomy, Kerala University of Fisheries \& Ocean Studies, Kochi, Kerala, India

\section{English Editors}

Mrs. Mira Bhojwani, Pune, India

Dr. Fred Pluthero, Toronto, Canad

Mr. P. Ilangovan, Chennai, India

Web Development

Mrs. Latha G. Ravikumar, ZOO/WILD, Coimbatore, India

\section{Typesetting}

Mr. Arul Jagadish, ZOO, Coimbatore, India

Mrs. Radhika, ZOO, Coimbatore, India

Mrs. Geetha, ZOO, Coimbatore India
Fundraising/Communications

Mrs. Payal B. Molur, Coimbatore, India

Subject Editors 2018-2020

Fungi

Dr. B. Shivaraju, Bengaluru, Karnataka, India

Dr. R.K. Verma, Tropical Forest Research Institute, Jabalpur, India

Dr. Vatsavaya S. Raju, Kakatiay University, Warangal, Andhra Pradesh, India

Dr. M. Krishnappa, Jnana Sahyadri, Kuvempu University, Shimoga, Karnataka, India

Dr. K.R. Sridhar, Mangalore University, Mangalagangotri, Mangalore, Karnataka, India

Dr. Gunjan Biswas, Vidyasagar University, Midnapore, West Bengal, India

\section{Plants}

Dr. G.P. Sinha, Botanical Survey of India, Allahabad, India

Dr. N.P. Balakrishnan, Ret. Joint Director, BSI, Coimbatore, India

Dr. Shonil Bhagwat, Open University and University of Oxford, UK

Prof. D.J. Bhat, Retd. Professor, Goa University, Goa, India

Dr. Ferdinando Boero, Università del Salento, Lecce, Italy

Dr. Dale R. Calder, Royal Ontaro Museum, Toronto, Ontario, Canada

Dr. Cleofas Cervancia, Univ. of Philippines Los Baños College Laguna, Philippines

Dr. F.B. Vincent Florens, University of Mauritius, Mauritius

Dr. Merlin Franco, Curtin University, Malaysia

Dr. V. Irudayaraj, St. Xavier's College, Palayamkottai, Tamil Nadu, India

Dr. B.S. Kholia, Botanical Survey of India, Gangtok, Sikkim, India

Dr. Pankaj Kumar, Kadoorie Farm and Botanic Garden Corporation, Hong Kong S.A.R., China

Dr. V. Sampath Kumar, Botanical Survey of India, Howrah, West Bengal, India

Dr. A.J. Solomon Raju, Andhra University, Visakhapatnam, India

Dr. Vijayasankar Raman, University of Mississippi, USA

Dr. B. Ravi Prasad Rao, Sri Krishnadevaraya University, Anantpur, India

Dr. K. Ravikumar, FRLHT, Bengaluru, Karnataka, India

Dr. Aparna Watve, Pune, Maharashtra, India

Dr. Qiang Liu, Xishuangbanna Tropical Botanical Garden, Yunnan, China

Dr. Noor Azhar Mohamed Shazili, Universiti Malaysia Terengganu, Kuala Terengganu, Malaysia

Dr. M.K. Vasudeva Rao, Shiv Ranjani Housing Society, Pune, Maharashtra, India

Prof. A.J. Solomon Raju, Andhra University, Visakhapatnam, India

Dr. Mandar Datar, Agharkar Research Institute, Pune, Maharashtra, India

Dr. M.K. Janarthanam, Goa University, Goa, India

Dr. K. Karthigeyan, Botanical Survey of India, India

Dr. Errol Vela, University of Montpellier, Montpellier, France

Dr. P. Lakshminarasimhan, Botanical Survey of India, Howrah, India

Dr. Larry R. Noblick, Montgomery Botanical Center, Miami, USA

Dr. K. Haridasan, Pallavur, Palakkad District, Kerala, India

Dr. Analinda Manila-Fajard, University of the Philippines Los Banos, Laguna, Philippines

Dr. P.A. Sinu, Central University of Kerala, Kasaragod, Kerala, India

Dr. Afroz Alam, Banasthali Vidyapith (accredited A grade by NAAC), Rajasthan, India

Dr. K.P. Rajesh, Zamorin's Guruvayurappan College, GA College PO, Kozhikode, Kerala, India

Dr. David E. Boufford, Harvard University Herbaria, Cambridge, MA 02138-2020, USA

Dr. Ritesh Kumar Choudhary, Agharkar Research Institute, Pune, Maharashtra, India

Dr. Navendu Page, Wildlife Institute of India, Chandrabani, Dehradun, Uttarakhand, India

\section{Invertebrates}

Dr. R.K. Avasthi, Rohtak University, Haryana, India

Dr. D.B. Bastawade, Maharashtra, India

Dr. Partha Pratim Bhattacharjee, Tripura University, Suryamaninagar, India

Dr. Kailash Chandra, Zoological Survey of India, Jabalpur, Madhya Pradesh, India

Dr. Ansie Dippenaar-Schoeman, University of Pretoria, Queenswood, South Africa

Dr. Rory Dow, National Museum of natural History Naturalis, The Netherlands

Dr. Brian Fisher, California Academy of Sciences, USA

Dr. Richard Gallon, llandudno, North Wales, LL30 1UP

Dr. Hemant V. Ghate, Modern College, Pune, India

Dr. M. Monwar Hossain, Jahangirnagar University, Dhaka, Bangladesh

Mr. Jatishwor Singh Irungbam, Biology Centre CAS, Branišovská, Czech Republic.

Dr. Ian J. Kitching, Natural History Museum, Cromwell Road, UK

Dr. George Mathew, Kerala Forest Research Institute, Peechi, India

For Focus, Scope, Aims, and Policies, visit https://threatenedtaxa.org/index.php/JoTT/aims_scope
For Article Submission Guidelines, visit https://threatenedtaxa.org/index.php/JoTT/about/submissions
For Policies against Scientific Misconduct, visit https://threatenedtaxa.org/index.php/JoTT/policies_various 


\title{
Nomenclatural notes and report of Boehmeria penduliflora Wedd. ex D.G. Long from the Terai region of Uttar Pradesh, India
}

\author{
Amit Gupta ${ }^{1}\left(\mathbb{D}\right.$, Imtiyaz Ahmad Hurrah ${ }^{2}$ (D), Aparna Shukla ${ }^{3}$ (D) \& Vijay V. Wagh ${ }^{4}$ (D) \\ ${ }^{1,2,3 \& 4}$ Plant Diversity, Systematics and Herbarium Division, CSIR-National Botanical Research Institute, Rana Pratap Marg, \\ Lucknow, Uttar Pradesh 226001, India. \\ ${ }^{1,284}$ Academy of Scientific and Innovative Research (AcSIR), CSIR-HRDC Campus Ghaziabad, Uttar Pradesh 201002, India. \\ ${ }^{1}$ cnb09695@gmail.com, ${ }^{2}$ saithimtiyaz18@gmail.com, ${ }^{3}$ aparnashukla602@gmail.com, ${ }^{4}$ vijay.wagh@nbri.res.in (corresponding author)
}

Abstract: Boehmeria penduliflora Wedd. ex D.G.Long (Urticaceae) is rediscovered after 81 years in Barahi range of Pilibhit Tiger Reserve, Pilibhit district, Uttar Pradesh, India. In the present article, detailed description, digital photographs, illustration, nomenclature update and relevant notes are provided to facilitate easy identification.

Keywords: Boehmeria penduliflora, Uttar Pradesh, cystoliths, flora cluster

The family Urticaceae is commonly known as the nettle family, comprising ca. 54 genera and 2,600 species spread throughout the world in tropics, subtropics, and temperate regions (Christenhusz \& Byng 2016). This family is represented by 29 genera and 153 species in India (Karthikeyan 2000). The apomictic genus Boehmeria (Yahara 1990) is the largest genus in tribe Boehmerieae. After revisionary study 47 species were reported from both new world and old world (WilmotDear \& Friis 1996, 2013), of which 15-20 species are known from Indian territory, distributed mostly in tropical regions (Gaur 1999). Boehmeria penduliflora Wedd ex D.G.Long mostly occurs in eastern India, with maximum concentration in the Naga and Khasi hills of Assam and Meghalaya (Wilmot-Dear et al. 2013).

During field exploration in Pilibhit district of Uttar Pradesh, a few specimens belonging to the genus Boehmeria were collected by the last author (VVW). Based on critical microscopic examination and review of literature (Weddell 1854; Lindsat et al. 1874; Hooker 1885; Duthei 1915; Kanjilal 1933, 1940; Wilmot-Dear \& Friis 2013) the specimens were identified as Boehmeria penduliflora Wedd. ex D.G.Long. From Uttar Pradesh this species was first reported by Kanjilal (1933) in "Forest flora of Pilibhit, Oudh, Gorakhpur, and Bundelkhand", from Kanjilal onwards; there has been no collection of this species in Uttar Pradesh. Present study reports B. penduliflora from Uttar Pradesh after 81 years, and provides detailed description, updated nomenclature,

Citation: Gupta, A., I.A. Hurrah, A. Shukla \& V.V. Wagh (2021). Nomenclatural notes and report of Boehmeria penduliflora Wedd. ex D.G. Long from the Terai region of Uttar Pradesh, India. Journal of Threatened Taxa 13(14): 20261-20265. https://doi.org/10.11609/jott.6603.13.14.20261-20265

Copyright: (c) Gupta et al. 2021. Creative Commons Attribution 4.0 International License. JoTT allows unrestricted use, reproduction, and distribution of this article in any medium by providing adequate credit to the author(s) and the source of publication.

Funding: University Grant Commission, New Delhi: UGC Ref.No.:768/(CSIR-UGC NET June 2018).

Competing interests: The authors declare no competing interests.

Acknowledgements: The authors are thankful to: the director CSIR-National Botanical Research Institute, Lucknow for facilities and encouragement; the curators of various Indian herbaria for allowing us to study the specimens (CAL, LWG, ASSAM); the curators of K, BM, G, KATH, and M herbaria for providing access to the herbarium specimens online; the forest department of Pilibhit Tiger Reserve, Uttar Pradesh (India) for giving us permission for surveying the localities. The first author thanks the University Grant Commission, New Delhi for financial support (NBRI communication number: CSIR-NBRI_MS/2020/07/13).
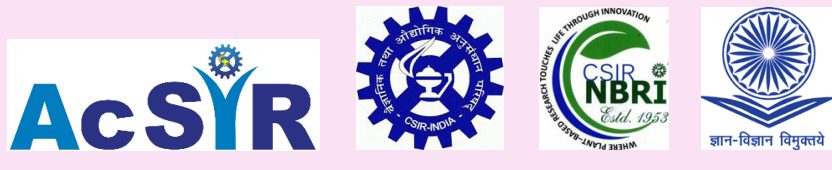


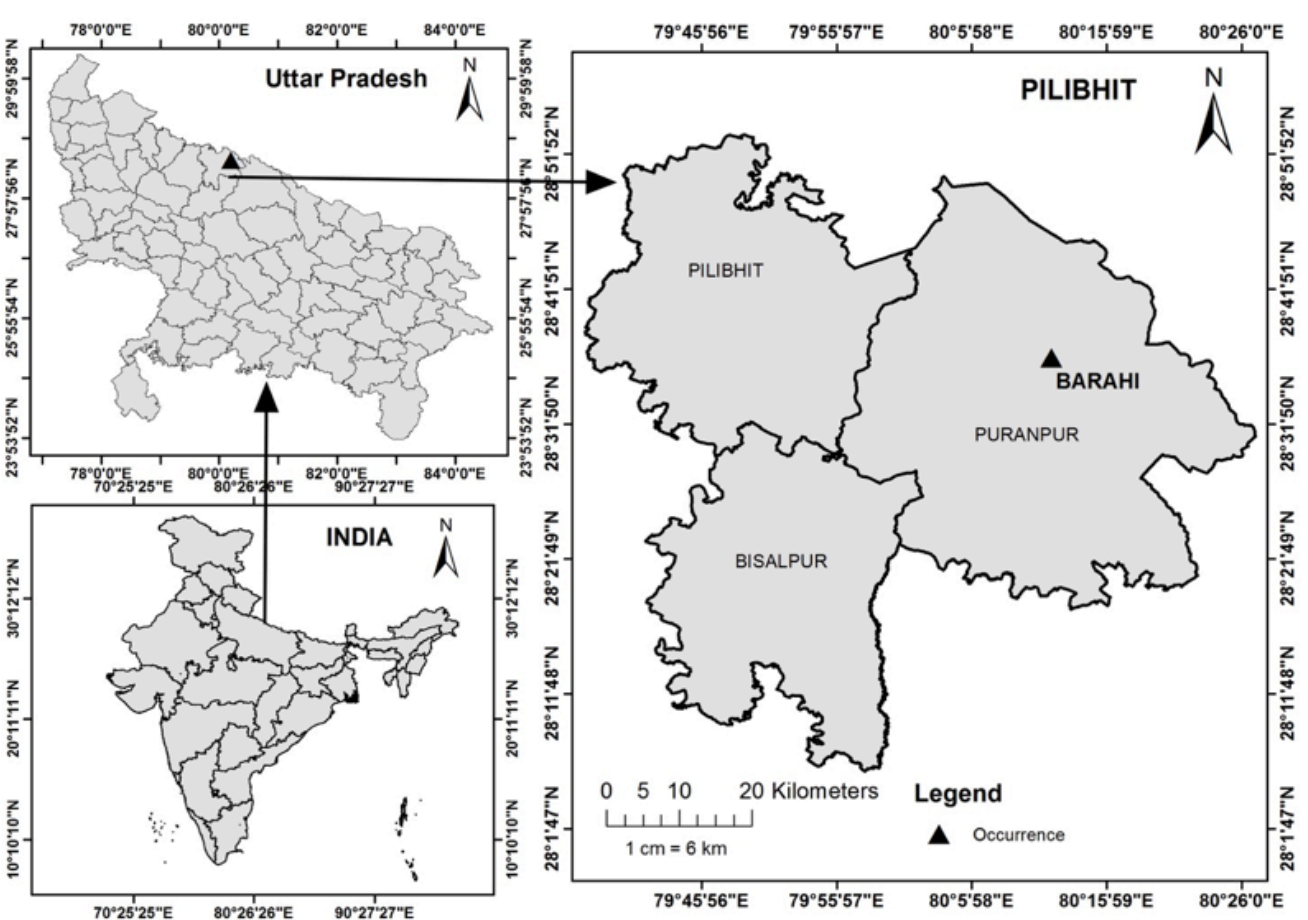

Figure 1. Collection locality of Boehmeria penduliflora Wedd. ex D.G.Long in Uttar Pradesh, in India.

phenology, photographs, illustration, and relevant notes to facilitate easy identification.

\section{MATERIAL AND Methods}

Fresh plant materials of Boehmeria were collected during field surveys conducted in Barahi forest range of Pilibhit Tiger Reserve, Uttar Pradesh, in 2014 (Figure 1). The habit, habitat features and the geo-coordinates (latitude/longitude/elevation) of each specimen were recorded. Macro and micro-morphological characters were examined critically in freshly collected and herbarium specimens. Plant parts were carefully studied under a stereomicroscope (Leica S8APO). Comparative studies were made by examining the relevant taxonomic literature (Yahara 1981; Friss 1993; Wilmot-Dear \& Friis 1996, 2013; Acharya et al. 2002). Specimens housed in ASSAM, BSD, BSHC, CAL, DD, and LWG were studied and digital specimen images were accessed from virtual herbaria of BM, E, G, K, NHNM, and NYBG. The Shenzhen Code (Turland et al. 2018) was followed for nomenclature updates and lectotypification of the plant names.

\section{TAXONOMIC TREATMENTS}

Boehmeria penduliflora Wedd. ex D.G.Long

in Notes Roy. Bot. Gard. Edinb. 40(1): 130. 1982. (Image 1-2; Figure 2-3)
= Boehmeria macrophylla D.Don (1825) 60, nom. illeg., non B. macrophylla Hornem. (1815).

= Boehmeria penduliflora Wedd. (1854) Ann. Sci. Nat., Bot. sér. 4, 1: 199 (1854).

= Boehmeria densiflora Hook \& Arn. var. penduliflora (Wedd. ex D.G.Long) Acharya \& Yonek., Acta Phytotax. Geobot. 53(1): 6.

Type: Nepal, Narainhetty, 5.ix.1802. BuchananHamilton s.n. Lectotype BM barcode BM000641028 (digital image !), selected by Long 1982: 130.

= Boehmeria densiflora Hook. \& Arn. var. intermedia Acharya \& Yonek., Acta Phytotax. Geobot. 53(1): 8(2002).

Type: Nepal, Gandaki Zone, Gorkha Dist., Dobremez 673; Holotype BM barcode BM00641035 (digital image !)

= Urtica penduliflora Wall., Numer. List [Wallich] n. 4595 (1831).

Lectotype (designated here): Nepal. Wallich, Numer. List.: No. 4595a, (G barcode G00354049 [digital image !]; isolectotype: K barcode K000741291 [digital image !])

Perennial, evergreen, small tree or undershrub, ca. $2 \mathrm{~m}$ tall. Ultimate stem 1-2 $\mathrm{mm}$ diameter, with appressed minute hairs. Leaves simple, opposite, superposed, slightly asymmetric; petiole $0.6-2.4 \mathrm{~cm}$ long, cylindrical, pubescent; lamina 9.4-24.6 × 1.6-3.3 $\mathrm{cm}$, lanceolate-ovate, obtuse or shortly attenuate base, acuminate apex, 3-veined at base, serrate-dentate 

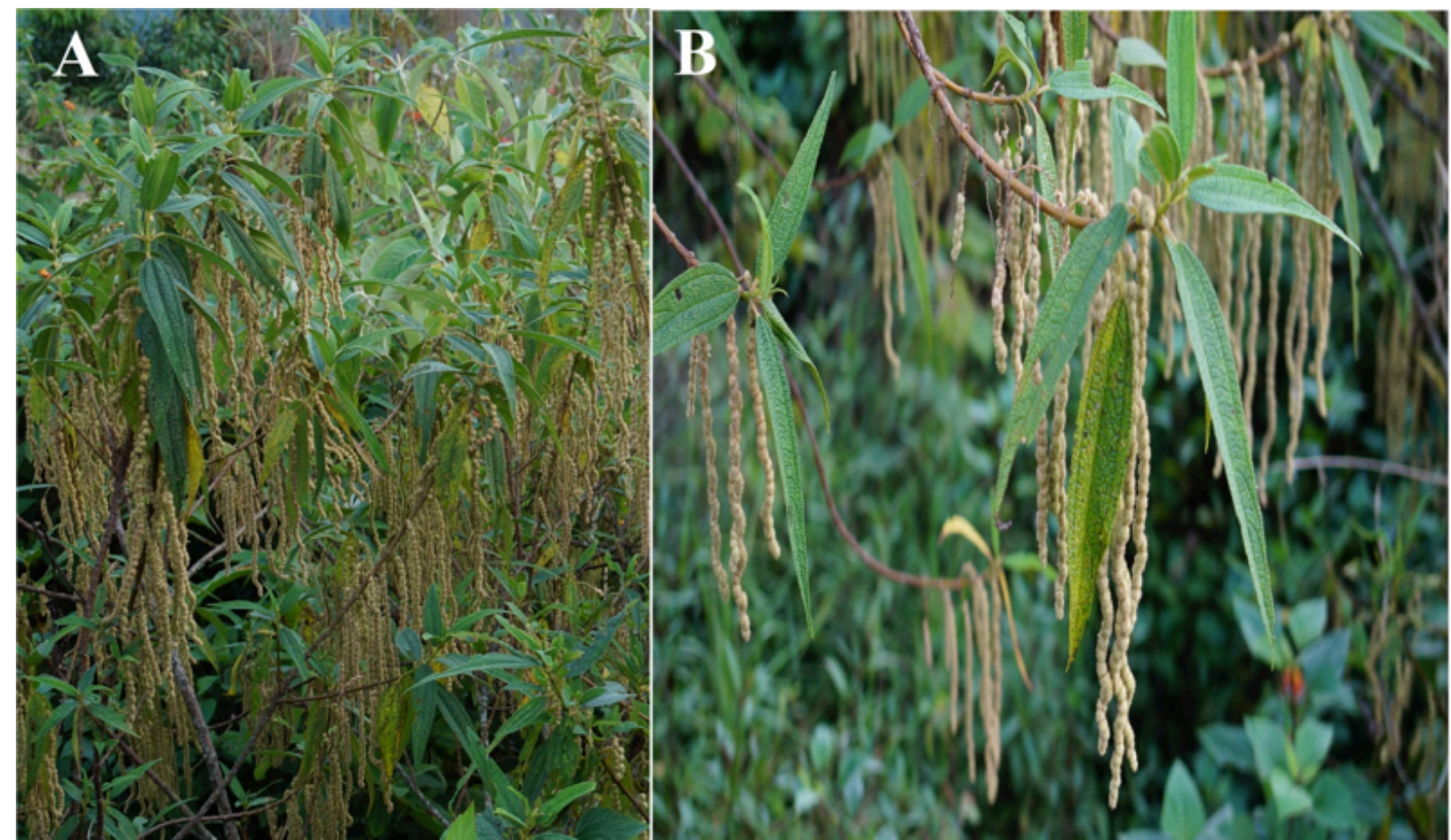

Image 1. A-Habit | B-Flowering twig of Boehmeria penduliflora Wedd. ex D.G. Long. ( Amit Gupta.

margins, adaxially with fine appressed eglandular hairs at young but nearly glabrate during maturation, dark green, leathery, fairly rough with punctuate cystoliths, abaxially having short dense thick hairs along main vein and lateral veins in younger and sparse in older ones, rest with tomentose hairs. Stipules $17 \times 2.3 \mathrm{~mm}$, falcate, free lateral, glabrate. Inflorescence borne on leaf axile, each inflorescence bearing axis unbranched or branched at base, having clusters of unisexual flowers; male axis towards the base of branches and comparatively shorter, 5-7 cm, pubescent, 5-10 flowers per cluster. Female axis $10-23 \mathrm{~cm}$ long, densely pubescent, each cluster $1.95-2.30 \times 1.6-2.8 \mathrm{~mm}, 0.69-23 \mathrm{~mm}$ apart consisting 40-74 flowers. Bract triangular, 2.5-3.4 × 1.19-1.23 mm, pubescent in centre and ciliate along margin; bracteoles inconspicuous. Male flower sessile or subsessile, tetramerous; tepals 4, elliptical, pubescent, fused in bud condition but open at maturity due to physical force applied by stamens; stamen 4 inflexed in bud, filament flattened, anther dithecous, basifixed, longitudinal dehiscent, surrounding the rudimentary carpel. Female flower 1.02-1.76 × 0.21-0.48 mm, sessile or subsessile, hypogynous; tepal attached with ovary, hairy 0.12-0.18 $\mathrm{mm}$ long; ovary $0.55-0.53 \mathrm{~mm}$ long, obovate, style $0.38-0.75 \mathrm{~mm}$, stigma penicilate. Fruit not seen.

Phenology: August to September
Notes: Boehemria penduliflora is distinct having flower clusters sparse, from B. densiflora with dense flower clusters. In addition, the upper surface of the leaf bears distinct punctate cystoliths. Young leaves and petiole are more pubescent than the older ones.

\section{Nomenclatural UPdATES}

Boehemria macrophylla D.Don was described by Don (1825) citing the type of Buchanan-Hamilton collection, mentioning type locality Narainhetty, Nepal. Exactly 10 year before, Hornemann in 1815 had described a new species with same name, i.e., Boehmeria macrophylla Hornem., and interestingly the two different specimens cited by D.Don and Hornemann individually, were collected by Buchanan Hamilton from same locality. As such D.Don's (1825) assigned name became the later homonym for Hornemann (1815) species and according to ICN later homonyms are illegitimates (Art. 53).

After that Wallich listed Urtica penduliflora Wall. (1831) in his numerical list publication, citing the specimen with collection number 4595a. As per www. plantlist.com database, and the current taxonomic status of $U$. penduliflora is considered as an unresolved name. Weddell (1854) gave a manuscript name Boehmeria penduliflora Wedd., without any description and was the first to cite Urtica penduliflora Wall. as a synonym 


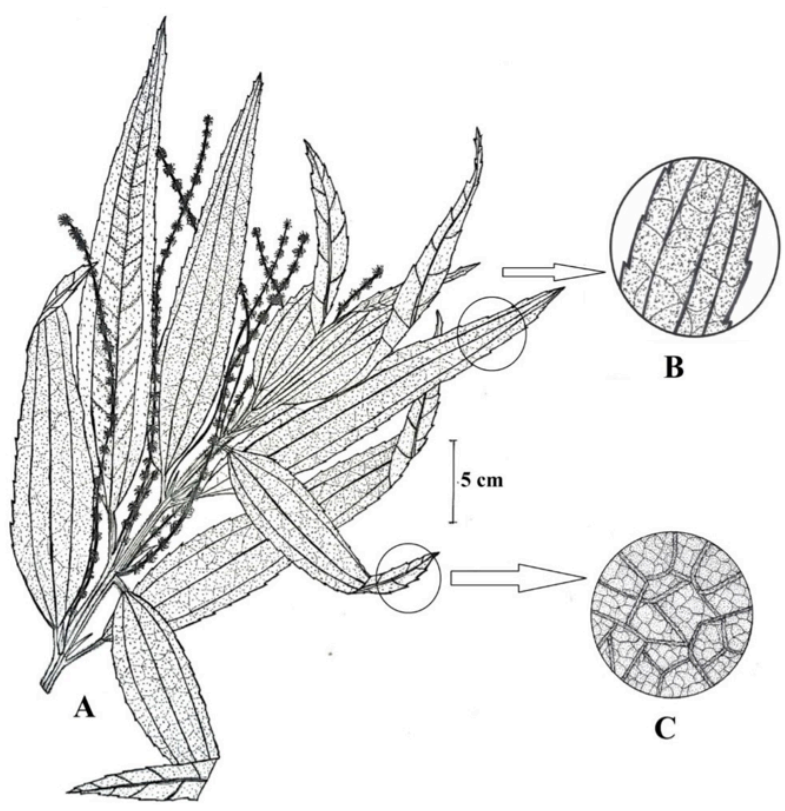

Figure 2. A-Flowering twig | B-Dorsal surface of the leaf | CVentral surface of the leaf of Boehmeria penduliflora Wedd. ex D.G.Long.

of B. penduliflora. But Weddell's name was not validly published (Art. 38.1). Later D.G. Long provided the detailed description and validly published Boehmeria penduliflora Wedd. ex D.G.Long (1982).

In the revisionary study of Boehmeria Jacq. in southeastern Asia, Acharya followed Wang's view (1995) and recognised $B$. densiflora as an accepted name and treated $B$. penduliflora as a variety of the former (Acharya et al. 2002). Acharya therefore proposed two varieties of $B$. densiflora, viz., $B$. densiflora var. penduliflora and $B$. densiflora var. intermidia which failed to get recognition and later rendered as synonyms of $B$. peduliflora as it gets the priority over Boehmeria densiflora.

The detailed critical study of Urtica penduliflora, based on the literature and virtual specimens, we were able to locate Wallich's collection of Urtica penduliflora from three different herbaria with same collection number 4595a, housed in K, G, and M herbarium (with barcodes K000741291, G00354049, and M0244322, respectively). As per ICN (Art. 9.6) the specimens deposited in $\mathrm{K}, \mathrm{G}$, and $\mathrm{M}$ becomes syntypes (Turland et al. 2018) and it is required to select one specimen as a lectotype amongst the three (Art 9.3, Note 2). Here we are designating the specimen housed at Geneva herbarium [G00354049] (Image 4) as lectotype and the one with barcode K000741291 as an isolectotype (Turland et al. 2018).

Habitat: In Barahi range of Pilibhit Tiger Reserve,

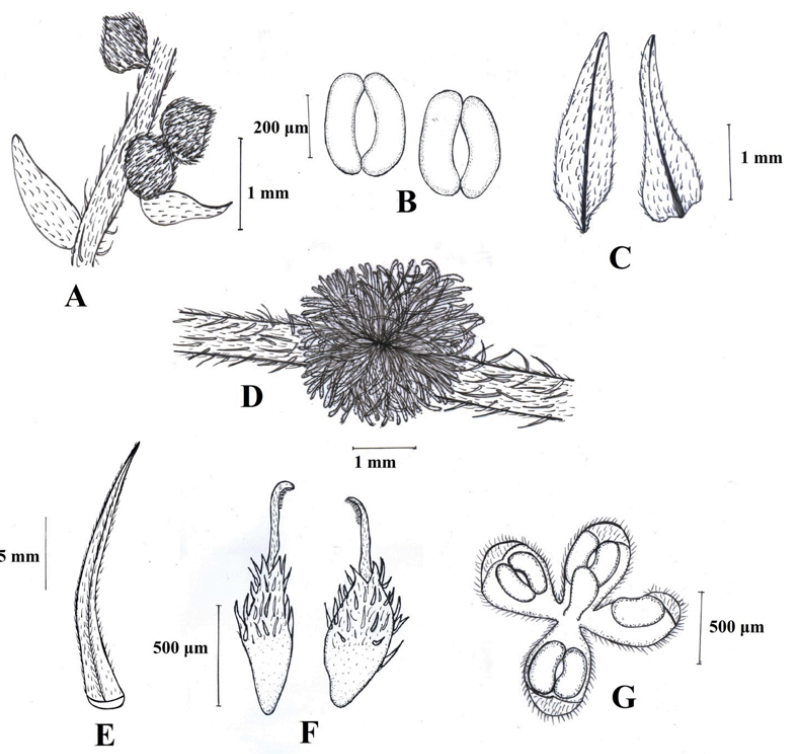

Figure 3. A-Male glomerulus | B-Anther | C-Bract | D-Female glomerulus | E-Stipule | F-Female flower | G-Male flower.

this species growing with ca. 10-15 individuals along the forest margins, on river bank and road side. The associated species are Cassia tora, Hyptis suaveolens, also growing under the Shorea robusta trees.

Specimen examined: Nepal, Narainhetty, 05.ix.1802, Buchanan, \# s.n., BM000641028 (BM); Wallich, N., 1821, \#4595a, G00354049 (G!), K000741291 (K!), M0244322 (M!); Jagat (Marsyandi), 28.483N,84.366E; $1300 \mathrm{~m}$, 28.xi.1970, Dobremez, J. F., \#673, BM006641028 (BM!), KATH01222 (KATH!); India, West Bengal, Jalpaiguri, Chilapata, 10.ix.1981, B. Jafari \& Party, 10456 (CAL); Assam, Pynursla, 25.xi.1956, G. Panigrahi, 4595; K \& G hills, Mawrynklang, 27.i.1957, G.K. Deka, 5233 (ASSAM); Khasi hill, 4000 ft., 09.x.1913, U. Kanjilal, 2668 (ASSAM); Rial khwan, Khasi Hill, 4500 ft, 29.x.1913, U. Kanjilal, 2463 (ASSAM); K \& J hill, Syndai, 500 m., 17.viii.1968, Balakrishnan, 46177 (ASSAM); K \& J hill, Mawrynklang, 27.i.1957, G.K. Deka, 5333 (ASSAM); K \& J hill, Unsav forest, 26.x.1938, S.R. Sharma 1729 (ASSAM); Meghalaya, Garo hill, Amchigiri, 220 m., 29.xi.1996, Sankar Dash, 105213 (ASSAM); Sensong, 25.ii.2007, 114288 (ASSAM); South Garo hill, Romper, 01.ii.2014, D.K. Roy, 91351 (ASSAM); K \& J hill, Barapani, 01.i.1930, P.C. Kanjilal, 8766 (ASSAM); K \& J hill, Nongpoh, 26.x.1938, S.R. Sharma, 17928 (ASSAM); Arunachal Pradesh, Tirap, Rusa, 08.ix.1958, G. Panigrahi, 17011 (ASSAM); Titap, Nonpong, 10.iii.1958, G.K. Murthy, 12995 (ASSAM); Kameng, 24.iii.1957, G. Panigrahi, 5937 (ASSAM); Siang, Koppu, 731 m., 08.xi.1958, R.S. Rao, 17454 (ASSAM); Siang, Kappu, 731 m., 08.xi.1958, R.S. 


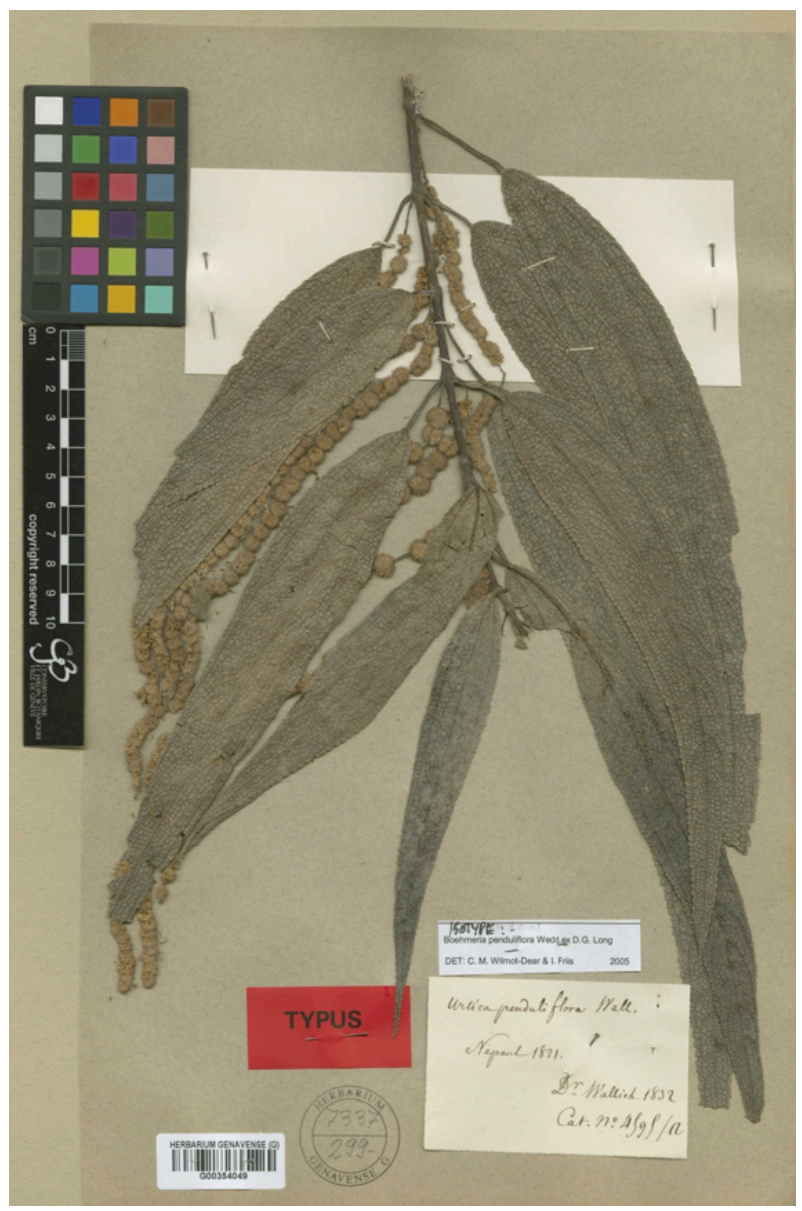

Image 2. Lectotype of Urtica penduliflora Wall. (G00354049). (C) Conservatoire et Jardin botaniques de la Ville de Genève.

Rao, 17459 (ASSAM); Kheti, 22.viii.1958, G. Panigrahi, 14601 (ASSAM); Tirap, Nampong, 12.x.1959, R.S. Rao, 20158 (ASSAM); Tirap, Nompong, 12.x.1959, R.S. Rao, 20005 (ASSAM); Kimin, Subansiri, 230 m., 24.ix.1954, G. Panigrahi, 19345 (ASSAM); Uttar Pradesh, Pilibhit district, Barahi Forest range, 28.602N, 80.182E, 275 m. 11.ix.2014, Vijay V. Wagh, 258047 (LWG).

Distribution: Boehmeria penduliflora is widely distributed in southeastern Asia (Acharya et. al. 2002). In India this species is mainly distributed in northeastern region of India like Assam, Meghalaya, Nagaland, Manipur (Wilmot-Dear \& Friis 2013) and also in terai region of Uttar Pradesh (Kanjilal 1933). We collected this species from Barahi range of Uttar Pradesh, on the bank of Sharada water canal (28.602N,80.182E, $275 \mathrm{~m})$.

\section{REFERENCES}

Acharya, N., K. Yonekura \& M. Suzuki (2002). A new species and a new variety of Boehmeria (Urticaceae) from the Himalaya with special reference to the status of $B$. penduliflora Wedd. ex DGLong. Acta Phytotaxonomica et Geobotanica 53(1): 1-9.

Christenhusz, M.J. \& J.W. Byng (2016). The number of known plants species in the world and its annual increase. Phytotaxa 261(3): 20-217.

Don, D. (1825). Prodromus Florae Nepalensis. J. Gale, Londini, 256pp.

Duthie, J.F. (1915). Flora of the upper Gangetic plain, and of the adjacent Siwalik and sub-Himalayan tracts. Supreintendent of Government Printing, Culcutta, 168pp.

Gaur, R.D. (1999). Flora of the District Garhwal, North West Himalaya. Transmedia.

Grierson A.J.C. \& D.G. Long (1982). Notes relating to the Flora of Bhutan 5. Notes from the Royal Botanic Garden, Edinburgh 40(1): $115-138$.

Hooker, J.D. (1888). Urticaceae, pp. 477-594. In: Hooker, J.D. (Eds.). The Flora of British India, Vol. 5. L. Reeve \& Co., London.

Hornemann, J.W. (1815). Hortus Regius Botanicus Hafniensis 2: 890.

Kanjilal, P.C. (1933). A Forest Flora of Pilibhit. Oudh, Gorakhpur and Bundelkhand. Allahabad.

Kanjilal, U.N., P.C. Kanjilal, A. Das, R.N. De \& N.L. Bor (1934-1940). Flora of Assam. Vols. 1-5. Government of Assam, Shillong.

Karthikeyan, S. (2000). A statistical analysis of flowering plants of India, pp. 201-217. Flora of India introductory volume part-II.

Kubitzki, K., J.G. Rohwer \& V. Bittrich (1993). Flowering Plants. Dicotyledons: Magnoliid, Hamamelid and Caryophyllid Families (Vol. 2). Springer Science \& Business Media.

Turland, N.J., J.H. Wiersema, F.R. Barrie, W. Greuter, D.L. Hawksworth, P.S. Herendeen, S. Knapp, W.H. Kusber, D.Z. Li, K. Marhold \& T.W. May (2018). International Code of Nomenclature for algae, fungi, and plants (Shenzhen Code) adopted by the Nineteenth International Botanical Congress Shenzhen, China, July 2017. Koeltz Botanical Books. Glashütten; 2018. (Regnum Veg. 159). https://doi. org/10.12705/Code.2018

Uniyal, B.P. (2007). Flowering plants of Uttarakhand (A Check List). Bishen Singh Mahendra Pal Singh. Dehradun, 404 pp.

Wallich, N. (1831). Numerical list of dried specimens in the museum of the honl. East India Company, London. https://doi.org/10.5962/ bhl.title.1917

Weddell, H.A. (1854). Revue de la famille de Urticacées. Annales des Sciences Naturelles; Botanique, Sér. 4(1): 173-212.

Weddell, H.A. (1856). Monographie de la famille des Urticées. Nouv. Archives du Muséum d'Histoire Naturelle 9: 1-400.

Weddell, H.A. (1857). Monographie de la famille des Urticées. Nouv. Archives du Muséum d'Histoire Naturelle 9: 401-592.

Weddell, H.A. (1869). Urticaceae. In: A. de Candolle (ed.), Prodromus systematis naturalis regni vegetabilis. Masson, Paris 6(1): 32-35

Wilmot-Dear, C.M. \& I. Friis (1996). The New World species of Boehmeria and Pouzolzia (Urticaceae, tribus Boehmerieae): a taxonomic revision. Opera Botanica 129, Copenhagen, 103 pp.

Wilmot-Dear, C.M. \& I. Friis (2013). The Old World species of Boehmeria (Urticaceae, tribus Boehmerieae). A taxonomic revision. Blumea-Biodiversity, Evolution and Biogeography of Plants 58(2): 85-216

Yahara, T. (1981). Taxonomic studies of the Urticaceae: 1 . The genus Boehmeria in Thailand. Acta phytotaxonomica et Geobotanica 32(14): 1-21.

Yahara, T. (1990). Evolution of agamospermous races in Boehmeria and Eupatorium. Plant Species Biology 5(1):183-96. 

Dr. John Noyes, Natural History Museum, London, UK

Dr. Albert G. Orr, Griffith University, Nathan, Australia

Dr. Sameer Padhye, Katholieke Universiteit Leuven, Belgium

Dr. Nancy van der Poorten, Toronto, Canada

Dr. Kareen Schnabel, NIWA, Wellington, New Zealand

Dr. R.M. Sharma, (Retd.) Scientist, Zoological Survey of India, Pune, India

Dr. Manju Siliwal, WILD, Coimbatore, Tamil Nadu, India

Dr. G.P. Sinha, Botanical Survey of India, Allahabad, India

Dr. K.A. Subramanian, Zoological Survey of India, New Alipore, Kolkata, India

Dr. P.M. Sureshan, Zoological Survey of India, Kozhikode, Kerala, India

Dr. R. Varatharajan, Manipur University, Imphal, Manipur, India

Dr. Eduard Vives, Museu de Ciències Naturals de Barcelona, Terrassa, Spain

Dr. James Young, Hong Kong Lepidopterists' Society, Hong Kong

Dr. R. Sundararaj, Institute of Wood Science \& Technology, Bengaluru, India

Dr. M. Nithyanandan, Environmental Department, La Ala Al Kuwait Real Estate. Co. K.S.C.,

Kuwait

Dr. Himender Bharti, Punjabi University, Punjab, India

Mr. Purnendu Roy, London, UK

Dr. Saito Motoki, The Butterfly Society of Japan, Tokyo, Japan

Dr. Sanjay Sondhi, TITLI TRUST, Kalpavriksh, Dehradun, India

Dr. Nguyen Thi Phuong Lien, Vietnam Academy of Science and Technology, Hanoi, Vietnam

Dr. Nitin Kulkarni, Tropical Research Institute, Jabalpur, India

Dr. Robin Wen Jiang Ngiam, National Parks Board, Singapore

Dr. Lional Monod, Natural History Museum of Geneva, Genève, Switzerland.

Dr. Asheesh Shivam, Nehru Gram Bharti University, Allahabad, India

Dr. Rosana Moreira da Rocha, Universidade Federal do Paraná, Curitiba, Brasi

Dr. Kurt R. Arnold, North Dakota State University, Saxony, Germany

Dr. James M. Carpenter, American Museum of Natural History, New York, USA

Dr. David M. Claborn, Missouri State University, Springfield, USA

Dr. Kareen Schnabel, Marine Biologist, Wellington, New Zealand

Dr. Amazonas Chagas Júnior, Universidade Federal de Mato Grosso, Cuiabá, Brasil

Mr. Monsoon Jyoti Gogoi, Assam University, Silchar, Assam, India

Dr. Heo Chong Chin, Universiti Teknologi MARA (UiTM), Selangor, Malaysia

Dr. R.J. Shiel, University of Adelaide, SA 5005, Australia

Dr. Siddharth Kulkarni, The George Washington University, Washington, USA

Dr. Priyadarsanan Dharma Rajan, ATREE, Bengaluru, India

Dr. Phil Alderslade, CSIRO Marine And Atmospheric Research, Hobart, Australia

Dr. John E.N. Veron, Coral Reef Research, Townsville, Australia

Dr. Daniel Whitmore, State Museum of Natural History Stuttgart, Rosenstein, Germany.

Dr. Yu-Feng Hsu, National Taiwan Normal University, Taipei City, Taiwan

Dr. Keith V. Wolfe, Antioch, California, USA

Dr. Siddharth Kulkarni, The Hormiga Lab, The George Washington University, Washington,

D.C., USA

Dr. Tomas Ditrich, Faculty of Education, University of South Bohemia in Ceske

Budejovice, Czech Republic

Dr. Mihaly Foldvari, Natural History Museum, University of Oslo, Norway

Dr. V.P. Uniyal, Wildlife Institute of India, Dehradun, Uttarakhand 248001, India

Dr. John T.D. Caleb, Zoological Survey of India, Kolkata, West Bengal, India

Dr. Priyadarsanan Dharma Rajan, Ashoka Trust for Research in Ecology and the Environment

(ATREE), Royal Enclave, Bangalore, Karnataka, India

\section{Fishes}

Dr. Neelesh Dahanukar, IISER, Pune, Maharashtra, India

Dr. Topiltzin Contreras MacBeath, Universidad Autónoma del estado de Morelos, México

Dr. Heok Hee Ng, National University of Singapore, Science Drive, Singapore

Dr. Rajeev Raghavan, St. Albert's College, Kochi, Kerala, India

Dr. Robert D. Sluka, Chiltern Gateway Project, A Rocha UK, Southall, Middlesex, UK

Dr. E. Vivekanandan, Central Marine Fisheries Research Institute, Chennai, India

Dr. Davor Zanella, University of Zagreb, Zagreb, Croatia

Dr. A. Biju Kumar, University of Kerala, Thiruvananthapuram, Kerala, India

Dr. Akhilesh K.V., ICAR-Central Marine Fisheries Research Institute, Mumbai Research

Centre, Mumbai, Maharashtra, India

Dr. J.A. Johnson, Wildlife Institute of India, Dehradun, Uttarakhand, India

Amphibians

Dr. Sushil K. Dutta, Indian Institute of Science, Bengaluru, Karnataka, India

Dr. Annemarie Ohler, Muséum national d'Histoire naturelle, Paris, France

\section{Reptiles}

Dr. Gernot Vogel, Heidelberg, Germany

Dr. Raju Vyas, Vadodara, Gujarat, India

Dr. Pritpal S. Soorae, Environment Agency, Abu Dubai, UAE.

Prof. Dr. Wayne J. Fuller, Near East University, Mersin, Turkey

Prof. Chandrashekher U. Rivonker, Goa University, Taleigao Plateau, Goa. India

Dr. S.R. Ganesh, Chennai Snake Park, Chennai, Tamil Nadu, India

Dr. Himansu Sekhar Das, Terrestrial \& Marine Biodiversity, Abu Dhabi, UAE
Birds

Dr. Hem Sagar Baral, Charles Sturt University, NSW Australia

Dr. Chris Bowden, Royal Society for the Protection of Birds, Sandy, UK

Dr. Priya Davidar, Pondicherry University, Kalapet, Puducherry, India

Dr. J.W. Duckworth, IUCN SSC, Bath, UK

Dr. Rajah Jayapal, SACON, Coimbatore, Tamil Nadu, India

Dr. Rajiv S. Kalsi, M.L.N. College, Yamuna Nagar, Haryana, India

Dr. V. Santharam, Rishi Valley Education Centre, Chittoor Dt., Andhra Pradesh, India

Dr. S. Balachandran, Bombay Natural History Society, Mumbai, India

Mr. J. Praveen, Bengaluru, India

Dr. C. Srinivasulu, Osmania University, Hyderabad, India

Dr. K.S. Gopi Sundar, International Crane Foundation, Baraboo, USA

Dr. Gombobaatar Sundev, Professor of Ornithology, Ulaanbaatar, Mongolia

Prof. Reuven Yosef, International Birding \& Research Centre, Eilat, Israel

Dr. Taej Mundkur, Wetlands International, Wageningen, The Netherlands

Dr. Carol Inskipp, Bishop Auckland Co., Durham, UK

Dr. Tim Inskipp, Bishop Auckland Co, Durham, UK

Dr. V. Gokula, National College, Tiruchirappalli, Tamil Nadu, India

Dr. Arkady Lelej, Russian Academy of Sciences, Vladivostok, Russia

Dr. Simon Dowell, Science Director, Chester Zoo, UK

Dr. Mário Gabriel Santiago dos Santos, Universidade de Trás-os-Montes e Alto Douro,

Quinta de Prados, Vila Real, Portugal

Dr. Grant Connette, Smithsonian Institution, Royal, VA, USA

Dr. M. Zafar-ul Islam, Prince Saud Al Faisal Wildlife Research Center, Taif, Saudi Arabia

Mammals

Dr. Giovanni Amori, CNR - Institute of Ecosystem Studies, Rome, Italy

Dr. Anwaruddin Chowdhury, Guwahati, India

Dr. David Mallon, Zoological Society of London, UK

Dr. Shomita Mukherjee, SACON, Coimbatore, Tamil Nadu, India

Dr. Angie Appel, Wild Cat Network, Germany

Dr. P.O. Nameer, Kerala Agricultural University, Thrissur, Kerala, India

Dr. Ian Redmond, UNEP Convention on Migratory Species, Lansdown, UK

Dr. Heidi S. Riddle, Riddle's Elephant and Wildlife Sanctuary, Arkansas, USA

Dr. Karin Schwartz, George Mason University, Fairfax, Virginia.

Dr. Lala A.K. Singh, Bhubaneswar, Orissa, India

Dr. Mewa Singh, Mysore University, Mysore, India

Dr. Paul Racey, University of Exeter, Devon, UK

Dr. Honnavalli N. Kumara, SACON, Anaikatty P.O., Coimbatore, Tamil Nadu, India

Dr. Nishith Dharaiya, HNG University, Patan, Gujarat, India

Dr. Spartaco Gippoliti, Socio Onorario Società Italiana per la Storia della Fauna "Giuseppe

Altobello", Rome, Italy

Dr. Justus Joshua, Green Future Foundation, Tiruchirapalli, Tamil Nadu, India

Dr. H. Raghuram, The American College, Madurai, Tamil Nadu, India

Dr. Paul Bates, Harison Institute, Kent, UK

Dr. Jim Sanderson, Small Wild Cat Conservation Foundation, Hartford, USA

Dr. Dan Challender, University of Kent, Canterbury, UK

Dr. David Mallon, Manchester Metropolitan University, Derbyshire, UK

Dr. Brian L. Cypher, California State University-Stanislaus, Bakersfield, CA

Dr. S.S. Talmale, Zoological Survey of India, Pune, Maharashtra, India

Prof. Karan Bahadur Shah, Budhanilakantha Municipality, Kathmandu, Nepal

Dr. Susan Cheyne, Borneo Nature Foundation International, Palangkaraja, Indonesia

Dr. Hemanta Kafley, Wildlife Sciences, Tarleton State University, Texas, USA

\section{Other Disciplines}

Dr. Aniruddha Belsare, Columbia MO 65203, USA (Veterinary)

Dr. Mandar S. Paingankar, University of Pune, Pune, Maharashtra, India (Molecular)

Dr. Jack Tordoff, Critical Ecosystem Partnership Fund, Arlington, USA (Communities)

Dr. Ulrike Streicher, University of Oregon, Eugene, USA (Veterinary)

Dr. Hari Balasubramanian, EcoAdvisors, Nova Scotia, Canada (Communities)

Dr. Rayanna Hellem Santos Bezerra, Universidade Federal de Sergipe, São Cristóvão, Brazil

Dr. Jamie R. Wood, Landcare Research, Canterbury, New Zealand

Dr. Wendy Collinson-Jonker, Endangered Wildlife Trust, Gauteng, South Africa

Dr. Rajeshkumar G. Jani, Anand Agricultural University, Anand, Gujarat, India

Dr. O.N. Tiwari, Senior Scientist, ICAR-Indian Agricultural Research Institute (IARI), New

Delhi, India

Dr. L.D. Singla, Guru Angad Dev Veterinary and Animal Sciences University, Ludhiana, India

Dr. Rupika S. Rajakaruna, University of Peradeniya, Peradeniya, Sri Lanka

Dr. Bahar Baviskar, Wild-CER, Nagpur, Maharashtra 440013, India

Reviewers 2018-2020

Due to pausity of space, the list of reviewers for $2018-2020$ is available online.

The opinions expressed by the authors do not reflect the views of the Journal of Threatened Taxa, Wildlife Information Liaison Development Society, Zoo Outreach Organization, or any of the partners. The journal, the publisher, the host, and the partners are not responsible for the accuracy of the political boundaries shown in the maps by the authors.

Journal of Threatened Taxa is indexed/abstracted in Bibliography of Systematic Mycology, Biological Abstracts, BIOSIS Previews, CAB Abstracts, EBSCO, Google Scholar, Index Copernicus, Index Fungorum, JournalSeek, National Academy of Agricultural Sciences, NewJour, OCLC WorldCat, SCOPUS, Stanford University Libraries, Virtual Library of Biology, Zoological Records.

NAAS rating (India) 5.64
Print copies of the Journal are available at cost. Write to:

The Managing Editor, JoTT,

c/o Wildlife Information Liaison Development Society,

No. 12, Thiruvannamalai Nagar, Saravanampatti - Kalapatti Road,

Saravanampatti, Coimbatore, Tamil Nadu 641035, India

ravi@threatenedtaxa.org 


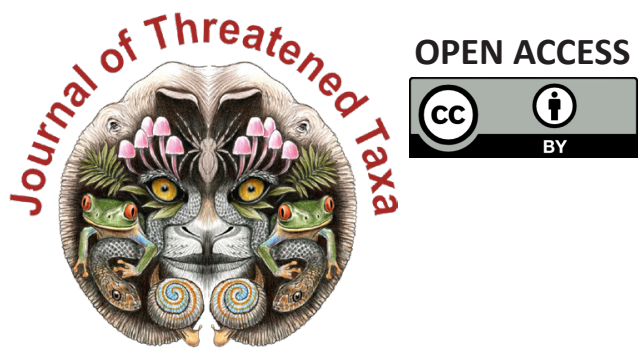

www.threatenedtaxa.org

The Journal of Threatened Taxa (JoTT) is dedicated to building evidence for conservation globally by publishing peer-reviewed articles online every month at a reasonably rapid rate at www.threatenedtaxa.org. All articles published in JoTT are registered under Creative Commons Attribution 4.0 International License unless otherwise mentioned. JoTT allows allows unrestricted use, reproduction, and distribution of articles in any medium by providing adequate credit to the author(s) and the source of publication.

\section{ISSN $0974-7907$ (Online) | ISSN $0974-7893$ (Print)}

\section{December 2021 | Vol. 13 | No. 14 | Pages: 20143-20310 \\ Date of Publication: 26 December 2021 (Online \& Print) DOI: 10.11609/jott.2021.13.14.20143-20310}

\section{Communications}

Updated distribution of seven Trichosanthes L. (Cucurbitales: Cucurbitaceae) taxa in India, along with taxonomic notes

Kanakasabapathi Pradheep, Soyimchiten, Ganjalagatta Dasaiah Harish, Muhammed Abdul Nizar, Kailash Chandra Bhatt, Anjula Pandey \& Sudhir Pal Ahlawat, Pp. 20143-20152

Dragonflies and Damselflies (Insecta: Odonata) of Aryanad Grama Panchayat, Kerala, India

- Reji Chandran \& A. Vivek Chandran, Pp. 20153-20166

Checklist of Odonata (Insecta) of Doon Valley, Uttarakhand, India

- Kritish De, Sarika Bhatt, Amar Paul Singh, Manisha Uniyal \& Virendra Prasad Uniyal, Pp. 20167-20173

Diversity of moths from the urban set-up of Valmiki Nagar, Chennai, India - Vikas Madhav Nagarajan, Rohith Srinivasan \& Mahathi Narayanaswamy, Pp. 20174-20189

Ichthyofaunal diversity with relation to environmental variables in the snowfed Tamor River of eastern Nepal

- Jawan Tumbahangfe, Jash Hang Limbu, Archana Prasad, Bhrarat Raj Subba \& Dil Kumar Limbu, Pp. 20190-20200

Observations on the foraging behavior of Tricoloured Munia Lonchura malacca (Linnaeus, 1766) and its interaction with pearl millet fields in Villupuram District, Tamil Nadu, India

- M. Pandian, Pp. 20201-20208

Roosting patterns of House Sparrow Passer domesticus Linn., 1758 (Aves: Passeridae) in Bhavnagar, Gujarat, India

- Foram P. Patel \& Pravinsang P. Dodia, Pp. 20209-20217

Review

Comprehensive checklist of algal class Chlorophyceae (sensu Fritsch, 1935) for Uttar Pradesh, India, with updated taxonomic status

- Sushma Verma, Kiran Toppo \& Sanjeeva Nayaka, Pp. 20218-20248

\section{View Point}

Wildlife managers ignore previous knowledge at great risk: the case of Rivaldo, the iconic wild Asian Elephant Elephas maximus L. of the Sigur Region, Nilgiri Biosphere Reserve, India

- Jean-Philippe Puyravaud \& Priya Davidar, Pp. 20249-20252

\section{Short Communications}

Diversity and distribution of macro lichens from Kalpetta Municipality of Wayanad District, Kerala, India

- Greeshma Balu, A.R. Rasmi, Stephen Sequeira \& Biju Haridas, Pp. 20253-20257

Extended distribution of two endemic epiphytes from the Western Ghats to the Deccan Plateau

- Sonali Vishnu Deore, Mangala Dala Sonawane \& Sharad Suresh Kambale, Pp. 20258-20260

Nomenclatural notes and report of Boehmeria penduliflora Wedd. ex D.G. Long from the Terai region of Uttar Pradesh, India

- Amit Gupta, Imtiyaz Ahmad Hurrah, Aparna Shukla \& Vijay V. Wagh, Pp. 2026120265
New distribution record of a true coral species, Psammocora contigua (Esper, 1794) from Gulf of Kachchh Marine National Park \& Sanctuary, India - R. Chandran, R. Senthil Kumaran, D.T. Vasavada, N.N. Joshi \& Osman G. Husen, Pp. 20266-20271

A new species of flat-headed mayfly Afronurus meenmutti (Ephemeroptera: Heptageniidae: Ecdyonurinae) from Kerala, India

- Marimuthu Muthukatturaja \& Chellaiah Balasubramanian, Pp. 20272-20277

Photographic record of Dholes predating on a young Banteng in southwestern Java, Indonesia

- Dede Aulia Rahman, Mochamad Syamsudin, Asep Yayus Firdaus, Herry Trisna Afriandi \& Anggodo, Pp. 20278-20283

Latrine site and its use pattern by Large Indian Civet Viverra zibetha Linnaeus, 1758: record from camera trap

- Bhuwan Singh Bist, Prashant Ghimire, Basant Sharma, Chiranjeevi Khanal \& Anoj Subedi, Pp. 20284-20287

Notes

Two additions to the flora of Kerala, India

- P. Murugan, Basil Paul \& M. Sulaiman, Pp. 20288-20291

Pentatropis R.Br. ex Wight \& Arn. (Apocynaceae), a new generic record for Kerala, India

- V. Ambika, Jose Sojan \& V. Suresh, Pp. 20292-20294

New record of Kashmir Birch Mouse Sicista concolor leathemi (Thomas, 1893) (Rodentia: Sminthidae) in the Indian Himalaya

- S.S. Talmale, Avtar Kaur Sidhu \& Uttam Saikia, Pp. 20295-20298

Breeding record of Black-headed Ibis Threskiornis melanocephalus (Aves: Threskiornithidae) at Mavoor wetland, Kozhikode District, Kerala, India - C.T. Shifa, Pp. 20299-20301

\section{Response}

Crop and property damage caused by Purple-faced Langurs Trachypithecus vetulus (Mammalia: Primates: Cercopithecidae) - Vincent Nijman, Pp. 20302-20306

Reply

If habitat heterogeneity is effective for conservation of butterflies in urban landscapes of Delhi, India? Unethical publication based on data manipulation: Response of original authors

- Monalisa Paul \& Aisha Sultana, Pp. 20307-20308

\section{Book Review}

Freshwater fishes of the Arabian Peninsula - Rajeev Raghavan, Pp. 20309-20310

Publisher \& Host

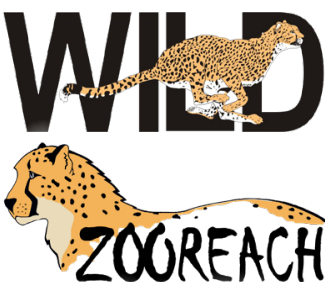

Threatened Taxa 